\title{
TINJAUAN KONTRIBUSI GOOGLE CLASSROOM DALAM MENDUKUNG PERKULIAHAN KIMIA DASAR
}

\author{
Eliyarti $^{1}$, Chichi Rahayu ${ }^{2}$, Zakirman $^{3}$ \\ ${ }^{1}$ Fakultas Teknik \& Perencanaan, Universitas Ekasakti, Padang, Indonesia \\ ${ }^{2}$ Pascasarjana Universitas Negeri Padang, Padang, Indonesia
}

\section{A R T I C L E I N F O \\ Article history: \\ Received 23 Februari 2020 \\ Received in revised form \\ 26 Februari 2020 \\ Accepted 28 Maret 2020 \\ Available online 30 April 2020}

Kata Kunci:

Kimia Dasar, google

classroom, deskriptif

\begin{abstract}
A B S T R A K
Pembelajaran yang monoton akan menyebabkan mahasiswa menjadi kurang aktif mengikuti perkuliahan kimia dasar. Sebagai solusi dilakukan kombinasi google classrrom dalam perkuliahan. Jenis penelitian ini deksriptif kualitatif bertujuan untuk mendeskipsikan perspektif mahasiswa dalam perkuliahan daring kimia dasar menggunakan google classroom. Instrumen data menggunakan kuisioner. Kuisioner digunakan untuk memperoleh data respon mahasiswa setelah menggunakan google classroom dalam empat kali sesi perkuliahan daring. Berdasarkan hasil dan pembahasan dapat disimpulkan bahwa dari 70 orang mahasiswa fakultas teknik Universitas Ekasakti 80,00\% meyatakan setuju google classroom mudah untuk dioperasikan, 64,28\% menyatakan setuju google classroom memberikan kemudahan dalam pengerjaan tugas, 88,57\% menyatakan setuju penggunaan google classroom memotivasi perkuliahan. Secara umum dapat kita lihat mahasiswa fakultas teknik Universitas Ekasakti memberikan respon positif dalam penggunaan google classroom dalam perkuliahan kimia dasar
\end{abstract}

\section{ABSTRACT}

Monotonous learning will make students to become less active in attending basic chemistry courses. As a solution a combination of Google classrrom is done in course. This type of descriptive qualitative research aimed to describe the perspective of students in basic online chemistry lectures using google classroom. Data instruments used questionnaires. The questionnaire was used to obtain student response data after using Google classroom in four online sessions. Based on the results and discussion, it can be concluded that from the seventy students of the Faculty of Engineering, Ekasakti University, $80.00 \%$ agreed that the Google classroom was easy to operate, $64.28 \%$ agreed that Google classroom made it easier to do assignments, $88.57 \%$ agreed to use Google. classroom motivates lectures. In general, we can see that the Faculty of Engineering students from Ekasakti University gave a positive response in using Google classroom in basic chemistry courses

Keywords: Basic Chemistry, google classroom, descriptive

\section{Pendahuluan}

Saat ini dunia telah memasuki era revolusi industri generasi 4.0 yang ditandai dengan peningkatan konektivitas, interaksi dan pengembangan sistem digital, kecerdasan buatan, dan virtual. Perubahan di era ini tidak dapat dihindari oleh siapa pun sehingga membutuhkan persiapan sumber daya manusia (SDM) yang memadai untuk siap menyesuaikan diri dan mampu bersaing dalam skala global. Meningkatkan kualitas sumber daya manusia melalui jalur pendidikan mulai dari pendidikan dasar dan menengah hingga pendidikan tinggi adalah kunci untuk dapat mengikuti perkembangan Revolusi Industri 4.0 (Gusta, Christina, \& Zakirman, 2020). Kehadiran IT tidak dapat dilihat sebagai sesuatu yang luar biasa, tetapi merupakan suatu keharusan untuk mempercepat perubahan dalam kualitas pendidikan dan pada

\footnotetext{
1 Corresponding author.

E-mail: rahayuchichi@gmail.com (Eliyarti)
} 
saat yang sama untuk meningkatkan daya saing peserta didik (Gustina, Ananda, Kosasih, Zakirman, \& Ardimen, 2020).

Bidang pendidikan memegang peranan penting dan strategis sebab merupakan sebuah wahana untuk meningkatkan kualitas sumber daya manusia (Zakirman, 2017). Tuntutan pendidikan yang sangat besar mendorong para akademisi untuk dapat berpartisipasi dalam berbagai perkembangan di dunia pendidikan (Putri, Ulhusna, Zakirman, \& Gusta, 2020). Tujuan utama pendidikan yaitu membuat perubahan dan mendidik peserta didik untuk meningkatkan kualitas hidup (Rahayu \& Eliyarti, 2019). Perubahan yang akan dilakukan dengan menambah wawasan dan pengetahuan sehingga memiliki kompetensi yang dapat digunakan di masa depan (Zakirman, Lufri, Khairani, \& Rahayu, 2020). Salah satu cara meningkatkan kompetensi peserta didik dengan penerapan teknologi sebagai media pembelajaran (Zakirman \& Hidayati, 2017).

Penggunaan teknologi tidak lagi diperuntukkan pada profesi tertentu namun telah heterogen dan menyebar. Berbagai kalangan memanfaatkan media komunikasi untuk memudahkan aktivitasnya, tak terkecuali para mahasiswa dan pelajar (Zakirman \& Rahayu, 2018). Dampak dan kualitas pendidikan dapat dibentuk dan ditentukan oleh kualitas pembelajaran (Zakirman, Lufri, \& Khairani, 2018). Dalam kegiatan pembelajaran mahasiswa membutuhkan motivasi. Dosen memiliki peranan penting untuk menumbuhkan motivasi belajar mahasiswa (Rahayu, Eliyarti, \& Festiyed, 2019). Motivasi menjadi proses yang menjelaskan intensitas, arah dan ketekunan seseorang individu untuk mencapai tujuannya. Dengan adanya motivasi akan meningkatkan pengoptimalan aktivitas berpikir sehingga dapat meningkatkan kompetensi diri (Rahayu \& Festiyed, 2018). Motivasi juga berperan untuk mendorong mahasiswa agar berusaha dan bekerja keras demi mencapai sesuatu keberhasilan dan keunggulan serta berusaha menghindari kegagalan (Eliyarti \& Rahayu, 2019b). Dosen dapat menciptakan pembelajaran yang menarik sehingga dapat menumbuhkan motivasi belajar mahasiswa.

Pembelajaran saat ini, lebih diarahkan pada aktivitas modernisasi dengan harapan dapat membantu mahasiswa dalam mencerna materi perkuliahan secara interaktif, produktif, efektif, inspiratif, konstruktif, dan menyenangkan. Selain itu, mahasiswa juga diharapkan memiliki life skill dari aplikasi teknologi tersebut (Nirfayanti \& Nurbaeti, 2019). Melalui pembelajaran moda daring mahasiswa memiliki keleluasaan waktu belajar. Mahasiswa dapat belajar kapanpun dan di manapun. Mahasiswa dapat berinteraksi dengan dosen baik secara synchronous-interaksi belajar pada waktu yang bersamaan seperti dengan menggunakan video converence, telepon atau live chat, maupun asynchronousinteraksi belajar pada waktu yang tidak bersamaan melalui kegiatan pembelajaran yang telah disediakan secara elektronik. Dengan memanfaatkan TIK, mahasiswa secara penuh melakukan pembelajaran daring dengan mengakses dan mempelajari bahan ajar, mengerjakan latihan-latihan (tugas), berdiskusi dan berbagi ilmu pengetahuan dan pengalaman dengan mahasiswa pembelajar lainnya. Selama proses pembelajaran, mahasiswa dibimbing dan difasilitasi secara daring (Isman, 2013).

Pada tingkat pendidikan tinggi, mahasiswa dituntut untuk aktif dalam proses belajar mengajar melalui media yang ada, seperti perpustakaan, jurnal, maupun internet (daring). Hampir semua tugas yang diberikan di pendidikan tinggi umumnya menuntut mahasiswa untuk mencari literatur lain dan mengembangkan pola pikirnya sendiri guna penyelesaian tugas secara efektif (Eliyarti \& Rahayu, 2019a). Salah satu cara untuk melakukan prose pembelajaran secara daring dengan menggunakan Google Classroom. Pemanfaatan Google Classroom dapat melalui multiplatform yakni melalui komputer dan gawai. Dosen dan mahasiswa mengunjungi situs https://classroom.google.com atau dapat mengunduh aplikasi melalui playstore diandroid atau app store di IOS dengan keyword Google Classroom. Penggunaan tersebut tanpa dipungut biaya, sehingga pemanfaatannya dapat dilakukan sesuai kebutuhan (Gunawan \& Sunarman, 2017). Melalui aplikasi Google Classroom diasumsikan bahwa tujuan pembelajaran akan lebih mudah direalisasikan dan sarat kebermaknaan. Oleh karena itu, penggunaan Google Classroom ini sesungguhnya mempermudah dosen dalam mengelola pembelajaran dan menyampaikan informasi secara tepat dan akurat kepada mahasiswa (Sabran \& Sabara, 2004).

Penggunaan google classrom akan membuat pembelajaran menjadi lebih efektif terlebih lagi dosen dan mahasiswa bisa setiap saat bertatap muka melalui kelas online google classroom. Mahasiswa juga dapat belajar, menyimak, membaca, mengirim tugas, dari jarak jauh (Soni et al., 2018). Fitur yang ditawarkan google classroom diantaranya adalah:1) Dosen dapat membuat banyak kelas 2). Bisa mengedit gambar profil dan nama. 3).Assignment yang dapat diposting dosen sebagai PR (pekerjaan rumah) / tugas 4).Pengaturan jadwal event-event penting 5). Satu mahasiswa dengan banyak dosen 6).Bisa diakses melalui handphone (Fanny, 2019).

Kimia merupakan salah satu matakuliah dasar di fakultas teknik. Kimia adalah ilmu yang mempelajari mengenai komposisi, struktur, dan sifat zat atau materi dari skala atom (mikroskopik) hingga molekul serta perubahan atau transformasi serta interaksi mereka untuk membentuk materi yang ditemukan sehari-hari (Eliyarti \& Rahayu, 2019a). Karakteristik ilmu kimia antara lain: (1) sebagian 
besar konsepnya bersifat abstrak, sederhana, berjenjang, dan terstruktur; (2) merupakan ilmu untuk memecahkan masalah serta mendeskripsikan fakta fakta dan peristiwa-peristiwa (Mentari, Suardana, \& Wayan, 2014). Penelitian terdahulu dilakukan oleh Sitti Faika dan Sumiati Side menggunakan perkulihan luring menunjukan masih rendahnya penguasaan materi dalam perkuliahan kimia (Faika \& Side, 2011). Penelitian Aang Parade, Dewi Handayani, Sumpono menunjukan bahwa hasil belajar siswa yang diberi persiapan dirumah melalui media e-learning menunjukan hasil yang lebih baik (Parade, Handayani, \& Sumpono, 2018). Pembelajaran yang monoton akan berimbas pada tujuan pembelajaran yang pada dasarnya untuk meningkatkan hasil belajar mahasiswa dan membuat mahasiswa aktif menjadi tidak dapat tercapai.

Selain itu, kegiatan perkuliahan kimia dasar di FT Unes masih belum maksimal. Hal ini dapat dilihat dari rata -rata nilai ujjian teori secara klasikal adalah 71 dengan persentase mahasiswa yang lulus $41,82 \%$ dan yang tidak lulus $49,09 \%$. Sebagai solusi dari permasalahan tersebut maka perkuliahan dilakukan menggunakan kombinasi pembelajaran e-learning dan pembelajaran konvensional memanfaatkan google classrrom dalam perkuliahan kimia dasar. Pembelajaran e-learning tidak dapat dipisahkan dari pembelajaran konvensional. E-learning merupakan model pembelajaran yang memanfaatkan teknologi internet, dalam praktiknya pembelajaran online ini dapat dilakukan di mana saja dan kapan saja dengan karakteristik interaktif, efektif, mandiri, mudah diakses, dan memungkinkan pengayaan penggunaan teknologi (Fauzan \& Arifin, 2019). Hal ini sejalan dengan tuntutan pembelajaran abad 21 yang lebih menuntut belajar secara mandiri. Menciptakan lingkungan belajar melalui internet harus didukung berbagai sumber belajar sehingga dapat mewujudkan lingkungan belajar mandiri yang kondusif, dimana lingkungan belajar mengarah kepada pengembangan fasilitas yang memberikan kebebasan bagi mahasiswa untuk dapat memproses kegiatan pembelajaran dengan menyediakan dukungan yang fleksibel, dapat diakses, dan selalu ada ketika dibutuhkan dan juga adanya dukungan prospektif untuk mahasiswa (Dewi, 2017).

Selanjutnya mahasiswa diminta memberikan respon atau perspektif terhadap penggunaan google classroom. Secara umum respon atau perspektif dapat diartikan sebagai hasil atau kesan yang di dapat (ditinggal) dari pengamatan tentang subjek, peristiwa atau hubungan-hubungan yang diperoleh dengan menyimpulkan informasi dan menafsirkan pesan-pesan (Chairunnisa, 2017). Selanjutnya Hasriani menambahkan bahwa perspektif merupakan cara pandang yang muncul akibat kesadaran seseorang terhadap suatu isu yang terjadi. Perspektif dapat dijadikan penambah wawasan atau pengetahuan seseorang agar dapat melihat segala sesuatu yang terjadi dengan pandangan yang luas (Hasriani \& Raddhiyani, 2019). Diharapkan dengan mengetahui perspektif mahasiswa dalam menggunakan google classrooom dapat menjadi pertimbangan untuk meningkatakan kualitas perkuliahan. Sehingga dapat dituliskan tujuan penelitian ini untuk mendeskripsikan perspektif mahasiswa dalam perkuliahan daring kimia dasar menggunakan google classroom.

\section{Metode}

Jenis penelitian ini adalah deksriptif kualitatif yang bertujuan untuk mendeskipsikan perspektif mahasiswa dalam perkuliahan daring kimia dasar menggunakan google classroom. Penelitian ini dilakukan selama 4 bulan dari September hingga Desember 2019. Populasi penelitian ini adalah mahasiswa tingkat I Fakultas Teknik dan Perencanaan Universitas Ekasakti dalam perkuliahan Kimia Dasar semester ganjil 2019/2020 sejumlah 70 orang. Pengambilam sampel menggunakan teknik simple random sampling. Instrumen data menggunakan kuisioner. Kuisioner digunakan untuk memperoleh data respon mahasiswa setelah menggunakan google classroom dalam empat kali sesi perkuliahan daring.

Prosedur penelitian yang dilakukan adalah sebagai berikut: (1) penyusunan kuisioner, (2) penyebaran kuisioner kepada 70 orang responden, (3) analisa kuisioner, (4) menarik kesimpulan. kuisioner yang disebarkan berisi 3 item pertanyaan yang masing-masingnya dibutuhkan respon berupa ceklis ataupun uraian pada setiap kolom jawaban item sesuai dengan pendapat responden. Ringkasan poin pertanyaan pada kuisioner yang digunakan dalam penelitian ini disajikan pada tabel 1 berikut ini:

Tabel 1. Fokus pertanyaan kuisioner

No pertanyaan

fokus pertanyaan

\begin{tabular}{ll}
\hline 1 & Kemudahan mengoperasikan \\
\hline 2 & Kemudahan pengerjaan tugas kuliah \\
\hline 3 & Memotivasi perkuliahan
\end{tabular}




\section{Hasil dan pembahasan}

Dosen membuat kelas di Google Classroom terlebih dahulu. Setelah itu, mengundang mahasiswa melalui surel dari masing-masing mahasiswa atau dapat melalui kode kelas dari Google Classroom yang telah dibuat. Secara umum, data/materi untuk pembelajaran dapat diunggah dengan menggunakan pilihan pada "About" di Google Classroom. Kemudian materi diunggah melalui "Add Materials". Untuk memberitahukan mahasiswa jika materi telah diunggah, maka dapat menggunakan pilihan "Stream" di Google Classroom, kemudian pilih "Announcement" pada "+". Untuk menambahkan tugas dapat memilih "Assigments" pada "+". Untuk menambahkan pertanyaan atau kuesioner pada Google Classroom dapat memilih "Question" pada "+". Melalui button yang dimiliki oleh Google Classroom tersebut, maka aktivitas mahasiswa dapat dilihat dari laporan yang diberikan pada kelas Google Classroom. Apabila mahasiswa telah mengunggah hasil pekerjaannya maupun hasil kuesioner yang terdapat di Google Classroom, maka ada laporan "Done" pada halaman kelas Google Classroom.

Setelah menggunakan google classrom dalam empat kali sesi perkuliahan daring, setiap mahasiswa diminta untuk mengisi kuisioner. Secara umum hasil analisis respon mahasiswa dapat dilihat pada tabel 2 berikut:

Tabel 2. Hasil analsis respon mahasiswa

\begin{tabular}{|c|c|c|c|}
\hline \multirow{2}{*}{$\begin{array}{l}\text { No } \\
\text { pertanyaan }\end{array}$} & \multirow{2}{*}{ Fokus pertanyaan } & \multicolumn{2}{|c|}{ Tanggapan mahasiswa } \\
\hline & & Setuju (\%) & Tidak Setuju (\%) \\
\hline 1 & Kemudahan mengoperasikan & 80,00 & 20,00 \\
\hline 2 & Kemudahan pengerjaan tugas kuliah & 64,28 & 35,71 \\
\hline 3 & Memotivasi perkuliahan & 88,57 & 11,42 \\
\hline
\end{tabular}

Berdasarkan tabel 2 terdapat hasil yang bervariasi untuk masing-masing fokus pertanyaan. Fokus pertanyaan pertama diperoleh hasil dari 70 orang mahasiswa sebanyak 56 orang atau sekitar 80,00\% meyatakan setuju google classroom mudah untuk dioperasikan sedangkan 14 orang atau sekitar 20,00\%. Agar lebih memahami analisis ini disajikan dalam bentuk diagram sebagai berikut:

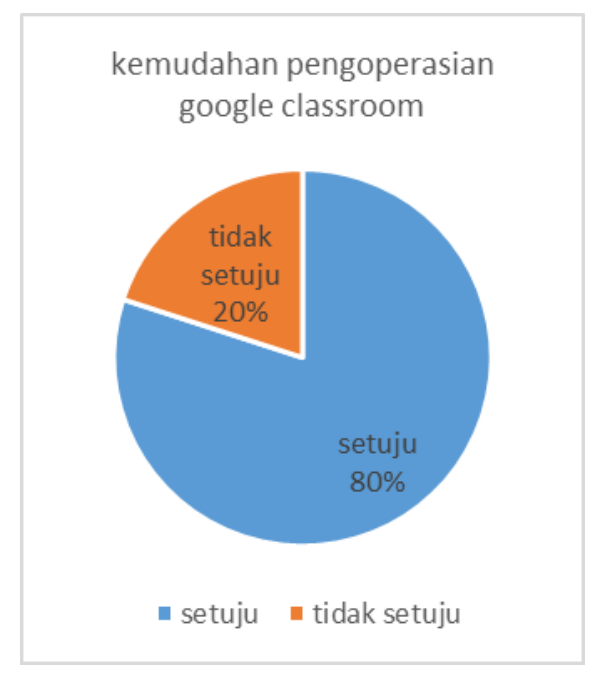

Gambar 1. Respon mahasswa tekait kemudahan pengoperasian google classroom

Untuk mengoperasikan google classroom tidak dibatasi pada browser tertentu. Sehingga ini memudahkan mahasiswa karena mereka tidak perlu menginstal browser tambahan. Mahasiswa dapat mengoperasikan google Classroom menggunakan internet di komputer dengan browser apa pun, seperti Chrome, Firefox ${ }^{\circledR}$, Internet Explorer $\AA$, atau Safari ${ }^{\circledR}$. Secara umum, google Classroom mendukung rilis browser utama secara berkelanjutan

Tingginya persentase mahasiswa yang memberikan tanggapan setuju menujukan respon positif mahasiswa terhadap penggunaan google classroom dalam perkuliahan kimia dasar. Google Classroom dianggap sebagai salah satu platform terbaik untuk meningkatkan kegiatan pembelajaran. Google Classroom menyediakan serangkaian fitur canggih yang menjadikannya alat yang ideal untuk digunakan bersama mahasiswa. Ruang kelas membantu dosen menghemat waktu, mengatur kelas, dan meningkatkan komunikasi dengan mahasiswa. Ini tersedia bagi siapa saja dengan Google Apps for 
Education, termasuk Gmail, Drive dan Documents (Iftakhar, 2016). Dengan demikian, google classroom cocok digunakan untuk kegiatan pembelajaran.

Pada fokus pertanyaan kedua menunjukan dari 70 orang mahasiswa 45 orang atau sekitar $64,28 \%$ menyatakan setuju google classroom memberikan kemudahan dalam pengerjaan tugas, sedangkan 25 orang atau sekitar $35,71 \%$ tidak setuju. Hal ini dapat disajikan dalam diagram berikut.

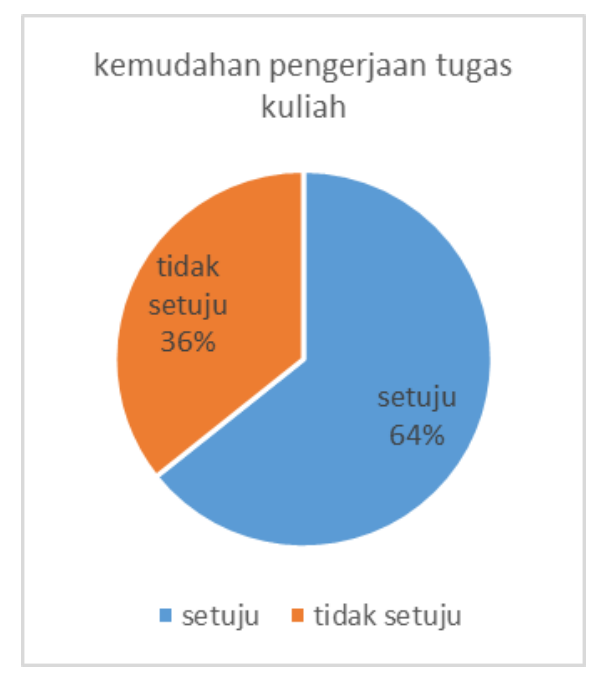

Gambar 2. Respon mahasiswa terkait kemudahan pengerjaan tugas kuliah menggunakan google classroom

Untuk mengerjakan tugas mahasiswa dapat memanfaatkan berbagai fitur dalam google classroom. Mahasiswa dapat melacak tugas kelas dan bahan ajar, berbagi materi dan berinteraksi dalam aliran kelas atau melalui email, mengirim tugas dan mendapat masukan dan nilai. Mahasiswa dapat melihat tugas di halaman tugas, di aliran kelas, atau di kalender kelas. Semua materi kelas otomatis disimpan dalam folder Google Drive.

Karakteristik pembelajaran secara online memberikan fleksibelitas mahasiswa untuk mengatur cara belajarnya sendiri (internal locus of control). Walaupun demikian, pembelajaran secara online ini juga mengarahkan pembelajaran dimulai dari ringkasan isi mengacu pada indikator menggunakan format materi yang ringkas dan dibuat non linear sebelum mengerjakan tugas. Pengenalan materi yang sifatnya esensial terkait dengan indikator sebelum dielaborasi lebih mendalam potensial memberikan kejelasan kepada mahasiswa terhadap pengetahuan apa yang menjadi fokus pembelajaran (Kirna, 2014). Namun, sebagian mahasiswa mengalami kesulitan mengerjakan tugas dengan menggunakan google classroom. Merujuk kepada hasil pengamatan, mahasiswa yang belum terbiasa dengan e-learning akan kebingungan menggunakan fitur pada google classroom.

Kegiatan online sebelum tatap muka difokuskan pada penyelesaian tugas-tugas mengacu pada indikator. Oleh sebab itu, setelah memperoleh gambaran tentang ringkasan Isi, mahasiswa dapat mengelaborasi pemahaman mereka melalui materi lengkap yang disajikan menggunakan format linear (PDF). Fleksibilitas sesungguhnya diberikan kepada mahasiswa untuk memulai pembelajaran dengan linklink modul yang disediakan. Tugas-tugas juga bisa dikerjakan secara simultan dengan eksplorasi materi, baik materi linear maupun nonlinear.

Pada fokus pertanyaan ketiga diperoleh hasil dari 70 orang mahasiswa 62 orang atau sekitar $88,57 \%$ menyatakan setuju penggunaan google classroom memotivasi perkuliahan, sedangkan 8 orang atau sekitar $11,42 \%$ tidak setuju. Hal ini dapat disajikan dalam diagram berikut 


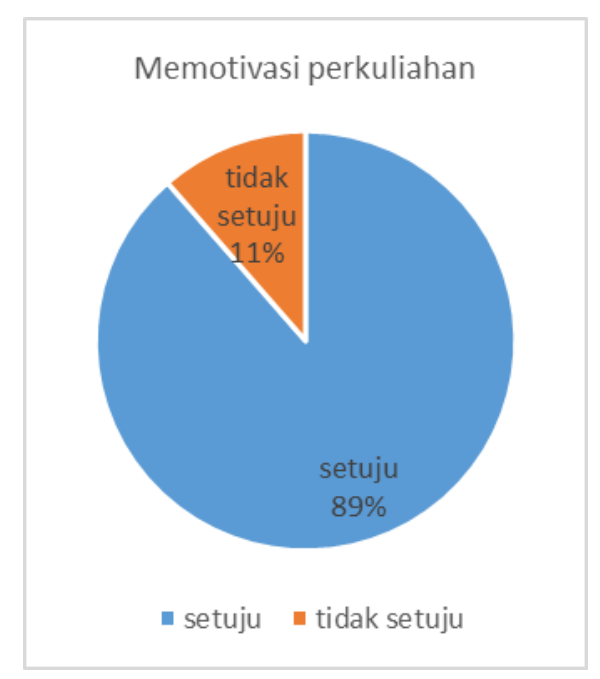

Gambar 3. Respon mahasiswa terkait memotivasi perkuliahan menggunakan google classroom

Merujuk pada konsep belajar dan pembelajaran bahwa belajar dapat dikatakan sebagai usaha untuk memperoleh kepandaian yang berguna dalam kehidupan manusia, sedangkan pembelajaran dapat dimaknai sebagai proses, cara atau tindakan yang dapat menjadikan seorang individu berilmu pengetahuan (Zakirman, 2019). Pembelajaran dengan google classroom memberikan suasana baru bagi mahasiswa sehingga kegiatan belajar menjadi tidak kaku dan mereka menjadi lebih termotivasi dalam perkuliahan. Dapat kita lihat pada tingginya persentase respon positif mahasiswa dalam penggunaan google classroom. Hal ini sejalan dengan pendapat Dina dkk bahwa pembelajaran e-learning merupakan perubahan kegiatan pembelajaran, yaitu mahasiswa diberikan kesempatan untuk berperan aktif dalam mengatur pembelajarannya secara mandiri, sehingga menghindarkan kesan membosankan didalam kelas dengan memanfaatkan teknologi informasi dan komputer (Dina \& Nugraheni, 2017)

Pendapat ini juga diperkuat oleh Much Fuad Saifuddin bahwa e-learning memberikan manfaat bagi mahasiswa dan dosen. Bagi mahasiswa, e-learning merupakan alternatif belajar dibandingkan pembelajaran konvensional dosen, dimana pembelajaran dapat berlangsung di luar ruang kuliah, membentuk kemandirian belajar, membantu menjadikan belajar sebagai belajar sepanjang hayat dan mendorong untuk berinteraksi antara siswa satu dengan yang lain. Sedangkan bagi dosen, elearningmengubah gaya mengajar yang berdampak pada profesionalitas kerja, memberi peluang menilai siswa dan mengevaluasi pembelajaran setiap siswa dan mengeksplorasi diri secara efisien (Saifuddin, 2017). Google Classroom memfasilitasi pembelajaran kolaboratif. Di sini dosen dapat mengunggah materi dan dapat memberikan umpan balik kepada mahasiswa. Mahasiswa juga dapat mengunggah materi dan membuat komentar pribadi. Selain itu, mahasiswa dapat berkolaborasi satu sama lain. Mereka dapat membagikan dokumen dan tugas mereka dan dengan demikian mereka dapat menghasilkan tugas terbaik (Iftakhar, 2016). Pembelajaran menggunakan google classroom memiliki beberpa keunggulan diantaranya :

a). Mudah digunakan sehingga menunjang kegiatan pembelajran

b). Menghemat waktu dan energi

c). Mudah mengupload tugas-tugas kuliah

d). Mudah untuk diakses baik dosen dan mahasiswa

\section{Simpulan dan saran}

Berdasarkan hasil dan pembahasan dapat disimpulkan bahwa dari 70 orang mahasiswa fakultas teknik Universitas Ekasakti 80,00\% meyatakan setuju google classroom mudah untuk dioperasikan sedangkan 20,00\% tidak setuju. Selanjutnya, 64,28\% menyatakan setuju google classroom memberikan kemudahan dalam pengerjaan tugas, sedangkan 35,71\% tidak setuju. Kemudian, 88,57\% menyatakan setuju penggunaan google classroom memotivasi perkuliahan, sedangkan 8 orang atau sekitar 11,42\% tidak setuju. Secara umum dapat kita lihat mahasiswa fakultas teknik Universitas Ekasakti memberikan respon positif dalam penggunaan google classroom dalam perkuliahan kimia dasar.

Sebagian mahasiswa memberikan respon negatif disebabkan masih banyak diantara mereka yang bingung cara menggunakan fitur-fitur yang ada pada google classroom. Untuk itu disarankan kepada dosen sebelum memberikan perkuliahan dengan google classroom melengkapi panduan penggunaan dan menjelaskan dengan detil kepada mahasiswa. 


\section{Daftar Rujukan}

Chairunnisa, C. (2017). Islam, Analisis Respon Mahasiswa Terhadap Mata Kuliah Terintegrasi Islami Kemuhammadiyahan dan Penghayatan Terhadap Nilai Agama. Faktor Jurnal Ilmu Kependidikan, 4(1), 9-22.

Dewi, L. (2017). Designing Online Learning in Higher education Institution: Case Study in Curriculum and Instruction Course at Indonesia University of Education. Edutech, 16(2), 205-221.

Dina, D., \& Nugraheni, A. R. E. (2017). Profil Kemandirian dan Minat Belajar Mahasiswa Pendidikan Kimia Pada Mata Kuliah Wawasan dan Kajian MIPA Melalui Pembelajaran E-Learning. Jurnal Inovasi Pendidikan Kimia, 11(2), 1921-1931.

Eliyarti, E., \& Rahayu, C. (2019a). Deskripsi Efektivitas Kegiatan Praktikum Dalam Perkuliahan Kimia Dasar Mahasiswa Teknik. Jurnal Pendidikan Kimia Indonesia, 3(2), 70-76.

Eliyarti, E., \& Rahayu, C. (2019b). Tinjauan Motivasi Berprestasi Mahasiswa Teknik Dalam Perkuliahan Kimia Dasar. Jurnal Pendidikan Glasser, 3(2), 196-204.

Faika, S., \& Side, S. (2011). Analisis Kesulitan Mahasiswa dalam Perkuliahan dan Praktikum Kimia Dasar di Jurusan Kimia FMIPA Universitas Neegeri Makassar. Jurnal Chemica, 12(2), 18-26.

Fanny, A. M. (2019). Pengaruh Pembelajaran E-Learing Terhadap Hasil Belajar Mahasiswa PGSD Pada Mata Kuliah Konsep IPS Lanjut. Jurnal Inventa, III(1), 130-135.

Fauzan, F., \& Arifin, F. (2019). The Effectiveness of Google Classroom Media on the Students ' Learning Outcomes of Madrasah Ibtidaiyah Teacher Education Department. AL IBTIDA: Jurnal Pendidikan Guru MI, 6(2), 271-285.

Gunawan, F. I., \& Sunarman, S. G. (2017). Pengembangan Kelas Virtual Dengan Google Classroom Dalam Keterampilan Pemecahan Masalah (Problem Solving) Topik Vektor Pada Siswa SMK Untuk Mendukung Pembelajaran. Seminar Nasional Etnomatnesia, 340-348.

Gusta, W., Christina, D., \& Zakirman, Z. (2020). Improved Student Collaboration Skills On English Learning Using Jigsaw Models. International Journal of Scientific \& Technology Research (IJSTR), 9(03), 10511056.

Gustina, G., Ananda, A., Kosasih, A., Zakirman, Z., \& Ardimen, A. (2020). Contribution Of Edmodo Smartphone Application To Support Assessment Activities In The Social Science Learning Process ; Students Review. International Journal of Scientific \& Technology Research (IJSTR), 9(03), 774-777.

Hasriani, G., \& Raddhiyani, F. (2019). Perspektif Mahasiswa terhadap Teknik Pembelajaran pada Mata Kuliah Speaking. Seminar Nasional, (April).

Iftakhar, S. (2016). Google classroom: What Works and How? Journal of Education Social Sciences, 3, 1218.

Isman, M. (2013). Pembelajaran Moda Dalam Jaringan (Moda Daring). The Progressive and Fun Education Seminar, 586-588.

Kirna, I. M. (2014). Pengembangan Konten Online Untuk Mendukung Blended Learning Pada Perkuliahan Kimia Kuantum Dasar. Cakrawala Pendidikan, XXXIII(2), 186-197.

Mentari, L., Suardana, I. N., \& Wayan, I. S. (2014). Analisis Miskonsepsi Siswa Sma Pada Pembelajaran Kimia Untuk Materi Larutan Penyangga. Journal Kimia Visvitalis Universitas Pendidikan Ganesha Jurusan Pendidikan Kimia, 2, 76-87.

Nirfayanti, N., \& Nurbaeti, N. (2019). Pengaruh Media Pembelajaran Google Clasroom Dalam Pembelajaran 
Analisis Real Terhadap Motivasi Belajar Mahasiswa. PROXIMAL: Jurnal Penelitian Matematika Dan Pendidikan Matematika, 2(1), 50-59.

Parade, A., Handayani, D., \& Sumpono, S. (2018). Menggunakan Media Internet Docs. Google Pada Pokok Bahasan Reaksi Redoks Kelas X IPA di SMAN 4 Kota Bengkulu. ALOTROP, Jurnal Pendidikan Dan Ilmu Kimia, 2(1), 8-13.

Putri, S. D., Ulhusna, M., Zakirman, Z., \& Gusta, W. (2020). Improvement of Student Science Literacy Skills Through Edmodo- Based Teaching Materials in Learning Science in Elementary School. International Journal of Scientific \& Technology Research (IJSTR), 9(03), 4649-4652.

Rahayu, C., \& Eliyarti, E. (2019). Implementation of Physics Learning Materials Based Generative Learning With Open-Ended Problem Approach To Stimulate Critical Thinking Skills. JIPF Ournal Ilmu Pendidikan Fisika), 4(2), 99. https://doi.org/10.26737/jipf.v4i2.1096

Rahayu, C., Eliyarti, E., \& Festiyed, F. (2019). Kepraktisan Perangkat Pembelajaran Berbasis Model Generative Learning dengan Pendekatan Open-ended Problem. Berkala Ilmiah Pendidikan Fisika, 7(3), 164-176. https://doi.org/10.20527/bipf.v7i3.6139

Rahayu, C., \& Festiyed. (2018). Validitas Perangkat Pembelajaran Fisika SMA Berbasis Model Pembeljaran Generatif Dengan Pendekatan Open-Ended Problem Untuk Menstimulus Keterampilan Berpikir Kritis Peserta Didik. Jurnal Pendidikan Fisika, 7(1), 1-6.

Sabran, S., \& Sabara, E. (2004). Keefektifan Google Classroom Sebagai Media Pembelajaran. Seminar Nasional Lembaga Penelitian Universitas Negeri Makassar, 122-125.

Saifuddin, M. F. (2017). E-Learning Dalam Persepsi Mahasiswa. Varia Pendidikan, 29(2), 102-109.

Soni, S., Hafid, A., Hayami, R., Fatma, Y., Wenando, F. A., Amien, J. Al, ... Hasanuddin, H. (2018). Optimalisasi Pemanfaatan Google Classroom Sebagai Media Pembelajaran di SMKN 1 Bangkinang. Jurnal Pengabdian Untuk Mu Negeri, 2(1), 17-20.

Zakirman, Z. (2017). Kelompok Gaya Belajar Reflektor Menurut Teori Honey Mumford Dalam Paradigma Perpustakaan. Shaut Al-Muktabah:Jurnal Perpustakaan, Arsip Dan Dokumentasi, 8(2), 133-142. https://doi.org/10.15548/shaut.v9i2.112

Zakirman, Z. (2019). Peningkatan Minat Baca Siswa Melalui Penerapan Model Pembelajaran Play-ThinkPair-Share di SDN 19 Nan Sabaris. Shaut Al-Maktabah: Jurnal Perpustakaan, Arsip Dan Dokumentasi, 11(1), 41-51. https://doi.org/10.15548/shaut.v11i1.162

Zakirman, Z., \& Hidayati, H. (2017). Praktikalitas Media Video dan Animasi Dalam Pembelajaran Fisika di SMP. Jurnal Ilmiah Pendidikan Fisika Al-Biruni, 06(April), 85-93. https://doi.org/10.24042/jpifalbiruni.v6i1.592

Zakirman, Z., Lufri, L., \& Khairani, K. (2018). Factors Influencing the Use of Lecture Methods in Learning Activities: Teacher Perspective. Advances in Social Science, Education and Humanities Research, 178(ICoIE 2018), 4-6.

Zakirman, Z., Lufri, L., Khairani, K., \& Rahayu, C. (2020). Implementation of The Play-Think-Pair-Share (PTPS) Learning Model for Elementary School Students to Master Part of Top Skill 2020. International Journal of Scientific \& Technology Research (IJSTR), 9(03), 4643-4648.

Zakirman, Z., \& Rahayu, C. (2018). Popularitas WhatsApp sebagai Media Komunikasi dan Berbagi Informasi Akademik Mahasiswa. Shaut Al-Maktabah: Jurnal Perpustakaan, Arsip Dan Dokumentasi, $10(1), 27-38$. 